AperTO - Archivio Istituzionale Open Access dell'Università di Torino

\title{
CLINICAL EVALUATION OF CIRCULATING MICRORNAS AS POTENTIAL BIOMARKERS OF HEPATOCELLULAR CARCINOMA IN PATIENTS WITH CHRONIC HBV INFECTION
}

\section{This is the author's manuscript}

Original Citation:

Availability:

This version is available http://hdl.handle.net/2318/157806

since 2017-02-06T17:19:54Z

Terms of use:

Open Access

Anyone can freely access the full text of works made available as "Open Access". Works made available under a Creative Commons license can be used according to the terms and conditions of said license. Use of all other works requires consent of the right holder (author or publisher) if not exempted from copyright protection by the applicable law. 


\section{(3) \\ UNIVERSITÀ DEGLI STUDI DI TORINO}

This is an author version of the contribution published on:

Questa è la versione dell'autore dell'opera:

Digestive and Liver Disease, Volume 47, Supplement 1, 2015, e1-e68.

The definitive version is available at:

La versione definitiva è disponibile alla URL:

http://www.dldjournalonline.com/issue/S1590-8658\%2814\%29X0020-4 


\title{
Clinical evaluation of circulating microRNAs as potential biomarkers of hepatocellular carcinoma in patients with chronic $\mathrm{HBV}$ infection
}

\author{
G.P. Caviglia ${ }^{1}$, M.L. Abate ${ }^{1}$, E. Petrini ${ }^{2}$, S. Gaia ${ }^{2}$, P. Manzini ${ }^{3}$, P. Carucci $^{2}$, M. Rizzetto ${ }^{1,2}$, A. \\ Smedile $e^{1,2}$ \\ ${ }^{1}$ Department of Medical Sciences, University of Turin, Turin, Italy \\ ${ }^{2}$ Department of Gastroenterology and Hepatology, Città della Salute e della Scienza \\ Hospital, Turin, Italy \\ ${ }^{3}$ Blood Bank, Città della Salute e della Scienza Hospital, Turin, Italy
}

Introduction. Several studies showed that aberrant miRNA expression is associated with development and progression of hepatocellular carcinoma (HCC).

Aim. To examine whether some commonly deregulated miRNAs (miR-122, miR-21, miR221 and miR-16) in HBV-related HCC may serve as diagnostic markers.

Materials and Methods. Serum expression of miR-122, miR-21, miR-221 and miR-16 was evaluated by real-time quantitative RT-PCR in 33 patients with HBV-related HCC $(61 \pm 10$ years; $\mathrm{F} / \mathrm{M}=4 / 29), 30$ patients with $\mathrm{HBV}$-related cirrhosis ( $53 \pm 11$ years; $\mathrm{F} / \mathrm{M}=11 / 19)$ and 27 blood donors as healthy controls $(54 \pm 8$ years; $\mathrm{F} / \mathrm{M}=9 / 18)$.

Results. Median levels of miR-16, miR-122 and miR-221 were significantly different in patients with HCC or cirrhosis compared to healthy controls $(\mathrm{p}<0.001)$ whereas, only miR122 levels differed in patients with HCC from cirrhotic patients $(\mathrm{p}=0.024)$. miR-122 levels were significantly higher in patients with multifocal HCC than in patients with a single lesion $(p=0.024)$. Expression levels of mir-21 were similar in the 3 groups. Area under the curve (AUC) analysis showed that serum levels of miR-122, miR-122+miR-221, miR$122+\mathrm{miR}-16$ and miR-122+miR-221+miR-16, are able to differentiate patients with $\mathrm{HCC}$ from patients with cirrhosis $(\mathrm{AUC}=0.675 ; \mathrm{AUC}=0.704 ; \mathrm{AUC}=0.681 ; \mathrm{AUC}=0.703$, respectively). Moreover, miR-16, miR-122 and miR-221, alone or in combination, were able to discriminate patients with HCC or cirrhosis from healthy controls (AUC>0.9). In addition, a correlation between miR-122 levels and HCC nodules number $(\mathrm{R}=0.390 ; \mathrm{p}=0.036)$, and between miR-16 and miR-122 levels, and ALT values $(\mathrm{R}=-0.464, \mathrm{p}=0.034 ; \mathrm{R}=0.449$, $\mathrm{p}=0.536$, respectively) was found.

Conclusions. Among the four microRNAs analyzed, only miR-122 significantly discriminates patients with $\mathrm{HCC}$ from cirrhotic patients and patients with $\mathrm{HCC}$ or cirrhosis from controls. miR-122 appears to reflect liver necro-inflammation, since we observed a positive correlation with ALT levels. Moreover, the correlation between miR-122 expression levels and HCC with multi-nodules, suggests the possible use of this miRNA for tumor stadiation. Nevertheless, miR-122 AUC values were not sufficiently high for HCC screening purposes. 